\title{
Changes in the inline lactate dehydrogenase according to the cow's production and reproduction status
}

\author{
Dovilė Malašauskienè ${ }^{1}$, Vida Juozaitiene ${ }^{2}$, Mindaugas Televičius ${ }^{1}$, Arūnas Rutkauskas ${ }^{1}$, \\ Mingaudas Urbutis ${ }^{1}$, Virginijus Kanapé ${ }^{3}$, Justina Gerbutavičiūte ${ }^{1}$, Ramūnas Antanaitis ${ }^{1}$ \\ ${ }^{1}$ Lithuanian University of Health Sciences, Veterinary Academy, Large Animal Clinic, Kaunas, Lithuania \\ ${ }^{2}$ Lithuanian University of Health Sciences, Veterinary Academy, Department of Animal Breeding, \\ Kaunas, Lithuania \\ ${ }^{3}$ Private Veterinary Practice, Kaunas, Lithuania
}

Received May 29, 2019

Accepted October 29, 2019

\begin{abstract}
The aim of the present study was to investigate inline lactate dehydrogenase (LDH) changes in clinically healthy dairy cows according to the number and stage of lactations, milk yield, and the reproduction status The $\mathrm{LDH}$ activity ( $\mu \mathrm{mol} / \mathrm{min}$ per litre) was measured using the drystick technology. A total of 378 cows were selected and classified according to their reproductive status into the following groups: fresh (1-44 days after calving); open (45-65 days after calving); inseminated (1-35 days after insemination); pregnant (35-60 days after insemination). According to their milk productivity, the cows were classified into the following groups: $<15 \mathrm{~kg} / \mathrm{d}$, $15-25 \mathrm{~kg} / \mathrm{d},>25-35 \mathrm{~kg} / \mathrm{d}$, and $>35 \mathrm{~kg} / \mathrm{d}$. They were milked with a DeLaval milking robot in combination with a Herd Navigator analyser. The results showed that the inline LDH concentration had a tendency to increase along with the increase in the number of lactation periods $(P<0.05)$. The highest level of LDH was observed in fresh cows 5-10 days in milk (DIM), and the highest $\mathrm{LDH}$ concentration was found in the milk of fresh cows. A positive statistically reliable relationship was found between the milk yield and LDH concentration $(P<0.05)$; LDH and milk somatic cell counts (SCC) were positively related in all groups of cows, although LDH concentration and SCC were the highest correlated variables in inseminated cows $(P<0.05)$. The present study shows that measuring LDH activity in milk is both easy and cost effective with high sensitivity and specificity, having a great potential as a diagnostic tool for detection of subclinical mastitis.
\end{abstract}

Production, herd navigator, mastitis, health, SCC

With inline monitoring, level shifts can be detected in real time as new observations are made. However, to use the continual stream of measurements, a framework that allows knowledge to accumulate is needed. The mathematical and statistical modelling of time series processes can be based on classes of state space models, also called dynamic models. Technological development has made it possible to conduct the automatic inline sampling and measurement of the components in milk. The lactate dehydrogenase (LDH) enzyme is found in the cytoplasm of all cells in the body, and during an inflammatory process involving cell damage and breakdown as observed during mastitis, it is released from the cells into the milk (Zank and Schlatterer 1998). In dairy milk, LDH is correlated with the somatic cell count (SCC) (Nyman et al. 2016), and is used as a mastitis indicator in commercial herd management (Friggens et al. 2007). The activity of LDH is increased because of mastitis (Fogs gaardet al. 2015). Previous studies have found a strong positive correlation between LDH and SCC (Zank and Schlatterer 1998; Hiss et al. 2007), and LDH is generally accepted as a useful mastitis indicator. However, the challenge of distinguishing between cows with latent infections and healthy cows based on LDH measurements has been described (His s et al. 2007). Attempts have been made to create mastitis detection systems using LDH as an indicator of infection. Chagunda et al. (2006) developed a dynamic deterministic model with a sensitivity and specificity for detecting 
clinical mastitis at a level of $82 \%$ and $99 \%$, respectively. In their study, healthy cows were defined as having no veterinary treatment within the incurrent lactation period and a SCC $<100,000$ cells $/ \mathrm{ml}$. The variation between cows and their immune response to subclinical mammary infection is a great challenge in the detection of subclinically infected cows through the observation of LDH levels (Jørgensen et al. 2016).

According to Nyman et al. (2014), further studies are needed to investigate whether the diagnostic properties of LDH will improve with adjustment according to their relationship with other different cow factors when used as a diagnostic tool for finding cows with mastitis. The aim of the present study was to investigate inline LDH dynamic changes according to different cow factors - the number and stage of lactations, milk yield, and the reproduction status in clinically healthy dairy cows.

The experiment was carried out on a dairy farm in the eastern region of Europe at $5600 \mathrm{~N} 2400 \mathrm{E}$, from January 15, 2017 to December 1, 2018. Lithuanian Black and White fresh dairy cattle were selected that had a second or higher lactations and were clinically healthy (during study) (an average rectal temperature of $+38.8^{\circ} \mathrm{C}$, rumen motility $\times 5-6$ per 3 min without signs of mastitis, lameness or metritis). The study was performed on 378 dairy cattle from a herd of 550 cows. The animals were kept in a loose housing system and were fed a feed ration throughout the year at the same time balanced according to their physiological needs. The cows were milked $\times 2$ per day at 06:00 $\mathrm{h}$ and 18:00 h, and the food was provided after each milking.

\section{Measurements}

For milk LDH detection the fully automated real-time analyser Herd Navigator (LattecI/S, Hillerød, Denmark) was used in combination with a DeLaval milking system (DeLaval Inc., Tumba, Sweden). This system also detected $\beta$-hydroxybutyrate and progesterone and urea concentration within the same group. An inline sampler in the milking robot automatically took a representative sample of several millilitres of milk from each cow during milking. The sample was then submitted to the Herd Navigator. Inline measurements of the LDH level and the data obtained and used in the present study were similar to the normal output data from the Herd Navigator system, so they were corrected using the procedure described below. In the Herd Navigator system, LDH activity levels $(\mu \mathrm{kat} / \mathrm{l})$ were measured using the dry-stick technology. After the milk sample was taken during milking, $10 \mu \mathrm{l}$ of the milk were applied to the indicator stick. The enzymatic reaction with LDH was coupled with a colour dye, and the intensity of the colour reaction after the application of the milk sample was measured using a digital camera. The raw measurements were corrected according to company-standardized methods to account for variations in the surrounding humidity and differences between the batches of dry sticks. Then, the most extreme outliers were removed. Measurements exceeding $200 \mu \mathrm{kat} / 1$ were set to a maximum value of 200 , and all negative values were deleted, because they were not in accordance with the normal range of measurements obtained from the Herd Navigator system. This editing of data is normal for data from the Herd Navigator system. Milk yield at the cow level was measured using an optical milk meter. The LDH concentration ( $\mu$ kat/l) was calculated as the LDH activity divided by the milk yield from each individual milking. The SCC was determined using the SomaScope (CA-3A4, Delta Instruments, the Netherlands) which operates on the principle of flow cytometry technology, and was carried out at the State Laboratory for Milk Control which operates under the requirements of ISO/IEC 17025:2005.

Animals and experimental condition

A total of 378 cows were selected. According to their reproductive status, the cows were classified as belonging to the following groups: fresh (5-44 days after calving); open (45-65 days after calving); inseminated (1-35 days after insemination); pregnant (35-60 days after insemination and pregnancy - relatively pregnant). According to their productivity, the cows were classified into the following groups: $<15 \mathrm{~kg} / \mathrm{d}, 15-25 \mathrm{~kg} / \mathrm{d},>25-35 \mathrm{~kg} / \mathrm{d}$, and $>35 \mathrm{~kg} / \mathrm{d}$. The cows were milked with a DeLaval milking system in combination with a Herd Navigator analyser.

\section{Data analysis and statistics}

The statistical analysis of data was performed using the SPSS 20.0 program package (SPSS Inc., Chicago, IL, USA). Using the descriptive statistics obtained, normal distributions were assessed for all variables by means of Kolmogorov-Smirnov test. The results were expressed as the mean $(\mathrm{M}) \pm$ standard of error of the mean (SEM) and a 95\% confidence interval (CI). The Pearson correlation (r) and linear regression were calculated in order to define the statistical relationship between the traits under investigation. In order to compare LDH concentrations between groups (according to the lactation, reproductive status, productivity and milk SCC), a one-factor analysis of variance (ANOVA) was applied. The differences between the means were evaluated by Fisher's LSD criterion. Student's $t$-test was used to find significant differences between groups by DIM. The relationships between the traits were analysed using Pearson's coefficient of correlation and linear regression analysis. A probability of $P<0.05$ was considered significant. 


\section{Results}

Changes in the milk LDH concentration of cows with different numbers and stages of lactation

The mean LDH concentration of cows was $25.8 \pm 0.8 \mu \mathrm{kat} / \mathrm{l}$. Table 1 summarizes significant differences between lactations $(P<0.05)$. We observed that the LDH concentration had a tendency to increase with an increase in the lactation number $\left(\mathrm{y}=6.616 \mathrm{x}+13.196, \mathrm{R}^{2}=0.999 ; P<0.05\right)$. The mean LDH concentration in cows of lactation $\geq 3$ was $66.9 \%$ higher in comparison with the $1^{\text {st }}$ lactation and $24.4 \%$ higher in comparison with the $2^{\text {nd }}$ lactation.

Table 1. Lactate dehydrogenase (LDH) concentration $(\mu \mathrm{kat} / \mathrm{l})$ in the milk of cows based on number of lactations.

The highest level of LDH $(50.28$

\begin{tabular}{lllc}
\hline Lactation & $\mathrm{M}$ & SEM & $95 \%$ PI \\
\hline $1 \quad(\mathrm{n}=147)$ & $19.7^{\mathrm{a}}$ & 1.338 & $17.1-22.3$ \\
$2 \quad(\mathrm{n}=114)$ & $26.5^{\mathrm{b}}$ & 1.509 & $23.5-29.4$ \\
$\geq 3 \quad(\mathrm{n}=117)$ & $33^{\mathrm{c}}$ & 1.527 & $29.9-36.0$ \\
\hline
\end{tabular}

${ }^{a b c}$ Means with different superscripts within columns differ significantly at $P<0.05 . \mathrm{M}$ - mean, SEM - standard of error of the mean, 95\% PI- confidence interval. $57.86 \mu \mathrm{mol} / \mathrm{min})$ was obtained from fresh cows, and ranged from 5 days in milk (DIM) to 10 DIM (Fig. 1). We observed that there was an increase in the LDH concentration from 10 DIM to 60 DIM during lactation (120.96\%, $P<0.05)$. We observed an increase in the level of LDH from 60 DIM to $110 \mathrm{DIM}(60.4 \%, P<0.05)$ and an increase from 110 DIM to 160 DIM (30.3\%, $P<0.05)$. We observed an increase $(50.3 \%, P<0.05)$ in the LDH concentration in the milk of cows at the end of lactation (from 250 DIM to 305 DIM).



Fig. 1. Lactate dehydrogenase (LDH) concentration ( $\mu \mathrm{kat} / \mathrm{l})$ in the milk of cows by days in milk (DIM).

\section{LDH in the milk of dairy cows during different stages of reproduction}

The obtained results demonstrated that the highest level of LDH concentration were found in the milk of fresh cows: $39 \%$ higher compared to open cows, $57 \%$ higher compared to inseminated cows, and $68.4 \%$ higher compared to pregnant cows $(P<0.05)$. Table 2 shows the average characteristics of LDH concentration based on the reproductive stages in dairy cows.

The comparison of the LDH concentration in the milk of cows represented differences between lactations for all the periods investigated in regard to their reproductive stage 
Table 2. Lactate dehydrogenase (LDH) concentration ( $\mu$ kat/l) in the milk of cows based on their reproductive stage.

\begin{tabular}{lllc}
\hline Productive stage & $\mathrm{M}$ & SEM & $95 \%$ PI \\
\hline Fresh $(\mathrm{n}=43)$ & $38.5^{\mathrm{a}}$ & 2.6 & $33.3-43.6$ \\
Open $(\mathrm{n}=78)$ & $27.6^{\mathrm{bc}}$ & 1.939 & $23.8-31.4$ \\
Inseminated $(\mathrm{n}=133)$ & $24.5^{\mathrm{b}}$ & 1.485 & $21.5-27.4$ \\
Pregnant $(\mathrm{n}=124)$ & $22.8^{\mathrm{bc}}$ & 1.538 & $19.8-25.8$ \\
\hline
\end{tabular}

${ }^{a b c}$ Means with different superscripts within columns differ significantly at $P<0.05$. M - mean, SEM - standard of error of the mean. $95 \%$ PI- confidence interval.

Table 3. Lactate dehydrogenase ( $\mathrm{LDH})$ concentration $(\mu \mathrm{mol} / \mathrm{min})$ in the milk of cows based on their level of productivity.

\begin{tabular}{lccc}
\hline Productivity $(\mathrm{kg} /$ day $)$ & $\mathrm{M}$ & SEM & $95 \%$ PI \\
\hline$<15(\mathrm{n}=51)$ & $26.0^{\mathrm{a}}$ & 2.510 & $21.1-30.9$ \\
$15-25(\mathrm{n}=158)$ & $22.2^{\mathrm{ab}}$ & 1.426 & $19.4-25.0$ \\
$>25-35(\mathrm{n}=138)$ & $29.7^{\mathrm{ac}}$ & 1.526 & $; 26.7-32.7$ \\
$>35(\mathrm{n}=31)$ & $31.4^{\mathrm{ac}}$ & 3.273 & $24.9-37.8$ \\
\hline
\end{tabular}

${ }^{a b c}$ Means with different superscripts within columns differ significantly at $P<0.05$. M - mean, SEM - standard of error of the mean, $95 \%$ PI- confidence interval.

The study revealed that there was a positive statistically reliable relationship between the milk yield of cows and their LDH concentration $(\mathrm{r}=0.139 ; P<0.05)$. However, we found the highest level of correlation between LDH and productivity in fresh cows, and the lowest coefficient of correlation was found in pregnant cows.

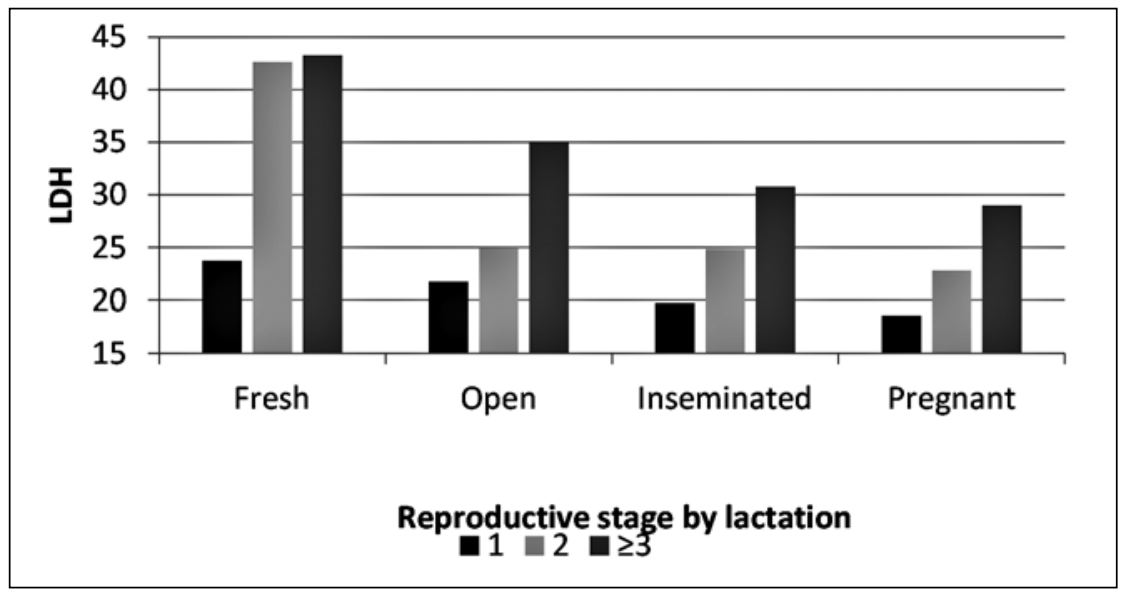

Fig. 2. Lactate dehydrogenase $(\mathrm{LDH})$ concentration $(\mu \mathrm{kat} / \mathrm{l})$ in the milk of cows according to their reproductive stage and lactation.

Fresh (5-44 days after calving); Open (45-65 days after calving); Inseminated (1-35 days after insemination); Pregnant (35-60 days after insemination and pregnancy - relatively pregnant). 


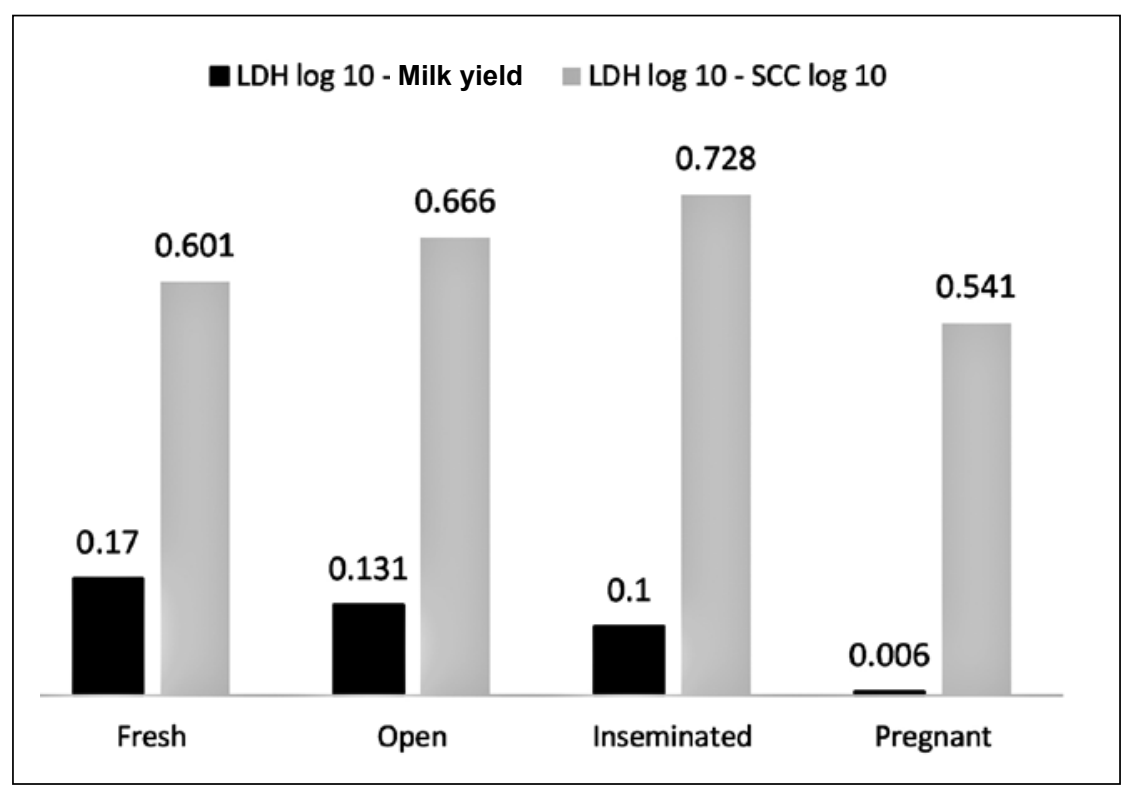

Fig. 3. Lactate dehydrogenase (LDH) correlation with the milk yield and somatic cells count (SCC) according to the reproductive status of cows.

Fresh (1-44 days after calving); Open (45-65 days after calving); Inseminated (1-35 days after insemination); Pregnant (35-60 days after insemination and pregnancy - relatively pregnant).

Table 4. Lactate dehydrogenase (LDH) concentration ( $\mu$ kat/l) in the milk of cows based on their somatic cell count (SCC).

\begin{tabular}{lccc}
\hline SCC $($ thousand $/ \mathrm{ml})$ & $\mathrm{M}$ & SEM & $95 \%$ PI \\
\hline$<100(\mathrm{n}=204)$ & $25.3^{\mathrm{a}}$ & 1.512 & $22.4-28.9$ \\
$100-200(\mathrm{n}=140)$ & $30.8^{\mathrm{b}}$ & 2.010 & $27.2-34.1$ \\
$>200-400(\mathrm{n}=19)$ & $35.6^{\mathrm{c}}$ & 2.264 & $31.2-38.1$ \\
$>400(\mathrm{n}=15)$ & $38.3^{\mathrm{c}}$ & 3.002 & $32.4-44.0$ \\
\hline
\end{tabular}

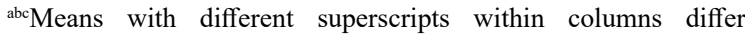
mean, $95 \%$ PI- confidence interval significantly at $P<0.05$. M - mean, SEM - standard of error of the

The correlation of LDH with milk SCC varied from 0.541 in pregnant cows to 0.728 in inseminated cows $(P<0.05)$.

\section{Discussion}

Lactate dehydrogenase, an enzyme whose activity increases because of mastitis, is used as an example of a mastitis indicator. It is a cytoplasmic enzyme involved in carbohydrate metabolism that gets released into milk from ruptured mammary epithelial cells, phagocytes and from serum resulting in a change in the physical and chemical properties of milk during mastitis (Singh et al. 2016). The additional factors incorporated in the model are the days from calving, breed, parity, milk yield, udder characteristics, other disease records, electrical conductivity, and herd characteristics (Chagunda et al. 2006). Certain enzyme levels increase in milk during intramammary infections (Anderi et al. 2011). Kalantari et al. (2013) showed that there is a significant positive correlation between the LDH levels observed in milk and somatic cells and on the other hand, no significant increase was seen in the activity of these enzymes in the blood serum of dairy cows with subclinical mastitis as compared to healthy cows. Observing the LDH activity in milk is both an easy and cost effective method when coupled with high sensitivity and specificity, and has 
a great potential as a diagnostic tool for the detection of sub-clinical mastitis (Singh et al. 2016).

According to the results of our study, the LDH concentration had a tendency to increase with the increase of the lactation number. In older cows (lactation $\geq 3$ ) LDH concentration was higher $(24.4-88.93 \%, P<0.05)$ compared to younger cows (in their $1^{\text {st }}$ and $2^{\text {nd }}$ lactations). The proposed milk enzymes $\beta$-glucuronidase and LDH might be indicative of inflammatory processes, but the influence of parity and the lactation stage on the overall results should be considered in the assessment of udder health in dairy goats (Stuhr and Aulrich 2010).

We observed a higher LDH concentration in fresh cows. According to previous research, the maximum value of LDH levels was demonstrated in a group of cows during their early lactation periods compared to the average activity of $\mathrm{LDH}$ in the blood of cows before calving and in lactating cows (Krsmanović et al. 2013). In dairy cows in puerperium, it caused a certain degree of fatty liver, which leads to the dysfunction of organs releasing enzymes of hepatocytes, thus the LDH level in the blood and its activity significantly increased (Djoković et al. 2013). High concentrations of LDH in cows at the peak of lactation indicate high odds of chronic lameness (Ristevski et al. 2017). According to literature, the udder is the preferred site to use glucose in dairy cows, so it is possible that the glucose that is introduced goes directly to the udder, where it is used. As a result, the muscle tissue continues to utilize glycolysis that further increases the lactate. In support of this speculation is the fact that the relation of LDH and glucose is significantly different, and shows an inverse relationship between healthy and lame cows (Ristevski et al. 2017).

A high LDH concentration could be a consequence of a higher beta-hydroxybutyrate concentration affecting the liver. High muscle damage leads to high lactate production, which is reduced by the LDH level in muscle tissues (Ristevski et al. 2017). Lactate dehydrogenase is not an organ-specific enzyme, as it is found in large concentrations in the muscles, heart, kidneys and liver, and is released during acute inflammations of those organs. Moreover, the activities of LDH in the blood are closely correlated with the degree of fatty infiltration of the liver (Pechova et al. 1997).

According to the results, the highest concentration $(31.4 \pm 3.2 \mu \mathrm{kat} / \mathrm{l})$ of LDH was observed in cows with a higher productivity, and there was a positive statistically reliable relationship between the milk yield of cows and LDH concentration. Results of the correlation matrix revealed significantly strong positive interdependence of SCC with enzyme LDH (Fig. 3). High correlation between LDH and SCC in subclinically infected buffaloes in the present study suggests that LDH activity can substitute SCC to detect subclinical mastitis in buffaloes. The present study shows that measuring LDH activity in milk is both easy and cost effective with high sensitivity and specificity, having a great potential as a diagnostic tool for detection of subclinical mastitis in buffaloes (Singh et al. 2016). The high number of somatic cells in the milk of about 250,000 cells per $\mathrm{ml}$ or more indicates mastitis (Table 4). In herds with milk tank somatic cells of less than 250,000 cells per ml show an appropriate level of udder health (Rasouli and Mosaferi 2017). Researchers found that eight days before the onset of clinical mastitis the LDH and somatic cells levels, would be increase $56 \%$. This change reflects the faster increasing of LDH compared to somatic cells (Rasouli and Mosaferi 2017). It was reported that the LDH activity in milk is an important indicator of mastitis and especially the increase of LDH provides an opportunity for early detection of mastitis in cows (Rasouli and Mosaferi 2017).

Based on the results of this study, we can state that inline LDH dynamic changes in the $\mathrm{LDH}$ concentration had a tendency to increase along with the increase in the number of lactation periods. The highest level of LDH observed in fresh cows was from 5 DIM to 10 
DIM, and the highest level of LDH concentration was found in the milk of fresh cows, and a positive statistically reliable relationship was found between the milk yield of cows and LDH concentration.

We can suggest for veterinarians that the inline LDH concentration correlated with the number of lactation periods. These are important facts to take into account during the diagnosis of subclinical mastitis in dairy cows.

\section{References}

Anderi S, Matei S, Fit N, Cernea C, Ciupe S, Bogdan S, Groza IS 2011: Glutathione peroxidase activity and its relationship with somatic cell count, number of colony forming units and protein content in subclinical mastitis cows milk. Rom Biotech Lett 16: 6209-6217

Chagunda MGGNC, Friggens MD, Rasmussen, Larsen T 2006: A model for detection of individual cow mastitis based on an indicator measured in milk. J Dairy Sci 89: 2980-2998

deMol RM, Keen A, Kroeze GH, Achten JMFH 1999: Description of a detection model for oestrus and diseases in dairy cattle based on time series analysis combined with a Kalman filter. Comput Electron Agric 22: 171-185

Djoković R, Kurćubić V, Ilić Z, Cincović M, Petrović M, Fratrić N, Jašović B 2013: Evaluation of metabolic status in Simmental dairy cows during late pregnancy and early lactation. Vet Arhiv 83: 593-602

Fogsgaard KKP, Løvendahl T, Bennedsgaard W, Østergaard S 2015: Changes in milk yield, lactate dehydrogenase, milking frequency, and interquarter yield ratio persist for up to 8 weeks after antibiotic treatment of mastitis. J Dairy Sci 98: 7686-7698

Friggens NC, Chagunda MG, Bjerring M, Ridder C, Højsgaard S, Larsen T 2007: Estimating degree of mastitis from time-series measurements in milk: A test of a model based on lactate dehydrogenase measurements. J Dairy Sci 90: 5415-5427

Hiss S, Mueller U, Neu-Zahren A,Sauerwein H 2007: Haptoglobin and lactate dehydrogenase measurements in milk for the identification of subclinically diseased udder quarters. Vet Med 52: 245-252

Jørgensen CH, Kristensen AR, Østergaard S, Bennedsgaard TW 2016:Use of inline measures of 1-lactate dehydrogenase for classification of posttreatment mammary Staphylococcus aureus infection status in dairy cows. J Dairy Sci 99: 8375-8383

Kalantari A, Safi S, Foroushani AR 2013: Milk lactate dehydrogenase and alkaline phosphatase as biomarkers in detection of bovine subclinical mastitis. AnnBiol Res 4: 302-307

Krsmanović M, Djoković R, Bojkovski J 2013: Determination of characteristic blood organic parameters in peripartal and peak lactation dairy cows. Bulletin of University of Agricultural Sciences and Veterinary Medicine Cluj-Napoca. Vet Med-US70: 258-265

Nyman AK, Emanuelson U, Waller KP 2016: Diagnostic test performance of somatic cell count, lactate dehydrogenase, and N-acetyl- $\beta$-d-glucosaminidase for detecting dairy cows with intramammary infection. J Dairy Sciv 99: 1440-1448

Nyman AK, Waller KP, Bennedsgaard TW, Larsen T, Emanuelson U 2014: Associations of udder-health indicators with cow factors and with intramammary infection in dairycows. J Dairy Scivv 97: 5459-5473

Pechova A, Illek J, Halouzka R 1997: Diagnosis and control of the development of hepatic steatosis in dairy cows in the periparturient period. Acta Vet Brno 66: 235-243

Rasouli A, Mosaferi S 2017: Accuracy rate of mastitis on-farm test (udder check) in comparison to somatic cell count (S.C.C.) in dairy herd. J Livestock Sci 8: 191-195

Ristevski M, Toholj B, Cincović M, Trojačanec P, Starič J, Smolec O 2017: Milk production, body condition score and metabolic parameters at the peak of lactation as risk factors for chronic lameness in dairy cows. Kafkas Univ Vet Fak 23: 5

Singh M, Sharma A, Mittal D, Yadav P, Charaya G 2016: Assessment of lactate dehydrogenase enzyme activity in milk as a marker for detection of subclinical mastitis. J Anim Res 6: 113

Stuhr T, Aulrich K 2010: Intramammary infections in dairy goats: recent knowledge and indicators for detection of subclinical mastitis. Landbauforschung 60: 267-279

Zank W, Schlatterer B 1998: Assessment of subacute mammary inflammation by soluble biomarkers in comparison to somatic cell counts in quarter milk samples from dairy cows. J Vet Med 45: 41-51 